\title{
Local energy mapping for enabling area-based energy reductions
}

\author{
Rajat Gupta ${ }^{1}$, Matt Gregg ${ }^{1}$ \\ ${ }^{1}$ Low Carbon Building Research Group, Oxford Institute for Sustainable Development \\ Oxford Brookes University, Oxford, UK
}

\begin{abstract}
This paper describes the application of a data-driven localised Geographical Information System (GIS)-based approach to model, map and manage domestic energy use and carbon emissions at a dwelling and neighbourhood level in Oxford (Oxfordshire, UK). Drawing on top-down and bottom-up datasets on local housing and energy, combined with engagement with an active community group for property-level data collection, appropriate dwellings are identified for deploying individual and combination of energy improvement measures. The neighbourhood energy model also helps to aggregate the demand for measures for cost effective energy action. The result of a complete retrofit of the mapped area is a projected $44 \%$ reduction in energy consumption and 38\% reduction in energy bills. Actioned results would enable reduction of both energy use and fuel poverty in the neighbourhood.
\end{abstract}

\section{Introduction}

According to the UK government's Department for Business, Energy and Industrial Strategy's (BEIS) Clean Growth Strategy (2018a), the UK has outperformed the target emissions reductions of the first carbon budget (2008 to 2012) by one per cent and project that the second and third budgets (2013 to 2022) will be surpassed by almost five per cent and four per cent respectively. Furthermore, the number of fuel poor households in England with an Energy Performance Certificate (EPC) efficiency rating $\mathrm{E}$ or below was reduced from 1.8 million in 2010 to 920,000 in 2015 through concerted effort. Carbon budget success to date is primarily attributed to significant improvement in the power and waste sectors; however, to move forward the remaining sectors will need to match in success.

A potential pathway to success in 2032 (fifth carbon budget) would require a $20 \%$ reduction in emissions from homes. This would potentially be a six to nine million properties insulated with a focus on fuel poverty. The UK Government has a statutory, albeit vague, target to raise as many fuel poor homes as is 'reasonably practicable' to EPC Band C by 2030, with milestones of Band E by 2020 and Band D by 2025. Broadly, the goal is to have as many homes as possible improved to EPC Band C by 2035 (BEIS, 2018a). However, according to IPPR (Emden, Murphy, \& Lloyd, 2018), the government's main policy aimed at achieving this target, the Energy Company Obligation (ECO), is insufficient and at the current rate of progress IPPR analysis shows that elevating all fuel-poor households to EPC band C would not be achieved until 2091 at the earliest.

Mass-retrofit, the process of improving the energy performance of multiple dwellings at a community or city scale, is necessary to meet these needs. Due to economies of scale, mass-retrofit can reduce capital costs, although there can be significant barriers, such as not all private dwellings agreeing to participate. Despite this, mass energy retrofit has several benefits versus an individual house approach that include:

- Ease of retrofit package development for dwelling clusters / streeets provided the relative homogeneity of urban/ suburban neighbourhoods/ streets in many areas of the UK (Gupta and Gregg, 2013).

- Economy of scale can reduce costs, e.g. required capital for tools and machinery, bulk material buying (Ariffin, Sulaiman, Mohammad, Yaman, \& Yunus, 2016; Cousins, Gitsham, \& Joss, 2010); resultant lower costs offer substantial motivation to homeowners (Cityfied Project, 2015).

- Potentially higher rate of shared information: willingness to participate in comparative social sharing of energy consumption following retrofit with neighbours with like-dwellings and like-retrofit works (Cabinet Office, 2011).

A long-standing challenge has been to target appropriate areas for mass energy retrofits. The EIT and NTU report (2018) recommends engagement with consumers through a single point of contact and aggregating projects into large blocks to attract investors and reduce costs.

To address this challenge, this paper proposes a new approach of engaging with neighbourhood community groups to gather property-level data for creating urban energy models, which can spatially identify local areas and aggregated demand for cost effective energy action (e.g. energy efficiency, generation).

\section{GIS energy models to enable retrofit}

As the need to retrofit the existing housing stock is a concern in many countries, there exists in the literature a widespread use of international examples of GIS modelling to explore the energy use and potential for districts and cities. 
Moghadam, Mutani, \& Lombardi (2016) use a bottomup approach to project the energy consumption at a district and city scale in Settimo Torinese, Italy using period of construction, built form and other census data including occupant count. Similarly, Caputo and Pasetti (2017) combined EPC data with other statistical data and regional data to derive energy consumption for GIS presentation in a medium sized municipality in the Lombardy region of Italy. Quan, Li, Augenbroe, Brown, \& Yang (2015) use basic building information, mutual shading, microclimate and occupant behaviour in and energy performance calculator engine to visualise energy consumption in New York, USA.

In both Italy (Delmastro, Mutani, \& Schranz, 2016) and the UK (CSE, 2017) thermal models based on actual consumption data have been used to evaluate space heating energy demand in order to optimise planning for district heat networks. de Santoli, Mancini, \& Garcia (2018) comparatively mapped energy consumption and renewable energy systems (RES) to identify the additional RES to provide energy independence to the Lazio region of Italy. Similarly, (Groppi, de Santoli, Cumo, \& Garcia, 2018) analysed the energy demand with PV and solar thermal renewables potential on a house-by-house basis for two areas in Ladispoli, Italy

Common to most studies above, the modelling approaches use both actual and statistical data; generally, most studies also combine both top-down and bottom-up data to visualise energy consumption and potential for improvement. Likewise, the following methodology combines top-down and bottom-up data at various scales to both identify areas of high energy consumption and fuel poverty and to create house-by-house maps to visualise energy consumption and retrofit potential. The aggregated method of calculation and map-based presentation used in this study allows the results to be scaled-up for larger application and assessment. Aggregated improvement measures, for example, hypothetically encourage bulk installations and drive down installation costs.

\section{Methodology}

A previous paper presented the methodological approach (Gupta and Gregg, 2018) by evaluating the energy consumption and fuel poverty hot-spots at a county level (Oxfordshire) and pin-pointing areas of focus at a neighbourhood level. This paper extends the research by creating house-by-house energy model for a specific neighbourhood and engaging with an active community group for property-level data collection, with the expectation that recommendations may potentially be implemented.

The methodology for the study is comprised of three principal steps:

1. Top-down assessment of area

2. Engagement with the local community to increase interest and gather bottom-up data

3. Neighbourhood modelling to assess energy consumption and retrofit potential

\section{Engagement with the local community}

This process began by contacting a local community action group (CAG) with which the authors have done previous work in Oxford (Bruce-Konuah and Gupta, 2017). Meeting with the community group representative provided the insight that the community group was interested in providing retrofit options for the 1930s dwellings in the area as a first step. Based on this, an area to be mapped was agreed upon with the CAG. The authors then designed a questionnaire to be sent out to the households in the area. Following a few pilot runs, the CAG then sent the questionnaire out to their email list and dropped leaflets off to the houses located in the immediate area to be mapped.

The questionnaire was created using Google Forms, open for a little over two months from the end of November 2018 and was incentivised with a $£ 50$ prize to one random winner. The questionnaire was designed to gather data for dwellings in the area on occupancy, construction details, energy use for lighting, cooking and appliances, details on renewables and eligibility for ECO funding.

\section{DECoRuM modelling}

A pre-exiting GIS-based carbon-mapping model called DECoRuM (Domestic Energy, Carbon counting and carbon Reduction Model) (Gupta, 2009; Gupta and Gregg, 2018) was used in this study to visualise energy consumption and retrofit potential in the area.

In the DECoRuM model, energy consumption and $\mathrm{CO}_{2} \mathrm{e}$ emissions are the result of heat loss calculations from fabric and ventilation characteristics, estimated energy use from heating, domestic hot water and electricity use as calculated using the Building Research Establishment's (BRE) Domestic Energy Model (BREDEM-12) and the UK Government's Standard Assessment Procedure (SAP). Data for calculations include actual house characteristics gathered from historic (Digimap) and current maps (OS Mastermap and Google street view), EPCs (MHCLG, 2017), literature describing home characteristics based on age and typology (e.g. Tabula/Episcope (BRE, 2014)), and completed questionnaires on home characteristics. Where questionnaire respondents give actual annual consumption data, this is prioritised; however, generally all available characteristic data are used to estimate annual energy use and emissions for the dwellings. For more details on the development of DECoRuM, the model inputs, assumptions and limitations please refer to Gupta and Gregg (2018).

Verification is performed by calibrating the aggregated energy consumption results to the sub-national energy consumption data for England and Wales at postcode scale (BEIS, 2017b). The results for each household are displayed on a map using GIS; in this instance, MapInfo. GIS allows any DECoRuM input or output variable to be mapped for visual communication, e.g. $\mathrm{kWh} /$ year, $\mathrm{CO}_{2} \mathrm{e}$ emissions $/ \mathrm{m}^{2} /$ year, homes in need of cavity wall insulation, PV suitability, etc. 


\section{Results}

\section{Top-down assessment}

Though sub-national data and EPC data were not used to identify the case study area as is done in Gupta and Gregg (2018), the relative position of the area was still reviewed using the publicly available datasets, i.e. the UK Government's sub-national energy (BEIS, 2017b) and fuel poverty (BEIS, 2017a) data at lower layer super output area (LSOA) (areas of approximately 400-800 dwellings) and EPC data, provided through open access by the Ministry of Housing, communities and Local Government (MHCLG, 2017b).

Table 1 shows the sub-national data comparisons between the case study area, Oxford City and Oxfordshire. The Rose Hill case study area $(\mathrm{RH})$ was found to have low gas consumption compared to Oxfordshire, i.e. up to $30 \%$ less than the mean and only $3 \%$ less than the Oxford City mean. At $11.8 \%$ fuel poor households, RH has a higher level of fuel poverty than the Oxfordshire mean but less fuel poor than Oxford City mean. Oxford City has the highest levels of fuel poverty in Oxfordshire; the 15 LSOAs with the highest fuel poverty (above 18\%) are all located in Oxford City. Rose Hill data also show (in parenthesis) the rank of the neighbourhood among the LSOAs in Oxfordshire. Note there are fewer gas registered LSOAs because 26 LSOAs are completely off the gas network. With respect to rankings, Rose Hill mapped area is most relevant regarding fuel poverty. The dwellings for which there are EPCs in the Rose Hill area $(n=180)$ have a lower EPC efficiency rating than the city and county but have a higher efficiency rating potential from EPC recommended measures.

Table 1: Sub-national \& EPC data.

\begin{tabular}{|l|l|l|l|}
\hline & $\begin{array}{l}\text { ROSE } \\
\text { HILL }\end{array}$ & $\begin{array}{l}\text { OXFORD } \\
\text { CITY }\end{array}$ & OX'SHIRE \\
\hline $\begin{array}{l}\text { Mean gas } \\
\text { consumption }\end{array}$ & $\begin{array}{l}12,455 \mathrm{kWh} \\
(257 \text { of } 381)\end{array}$ & $13,775 \mathrm{kWh}$ & $14,198 \mathrm{kWh}$ \\
\hline $\begin{array}{l}\text { Mean elec. } \\
\text { Consumption }\end{array}$ & $\begin{array}{l}3,064 \mathrm{kWh} \\
(401 \text { of } 407)\end{array}$ & $3,666 \mathrm{kWh}$ & $4,322 \mathrm{kWh}$ \\
\hline $\begin{array}{l}\text { Mean fuel } \\
\text { poverty }\end{array}$ & $\begin{array}{l}11.8 \% \\
(73 \text { of } 407)\end{array}$ & $12.9 \%$ & $9.6 \%$ \\
\hline $\begin{array}{l}\text { Mean EPC } \\
\text { band }\end{array}$ & $\mathrm{D}(63)$ & $\mathrm{D}(65)$ & $\mathrm{D}(64)$ \\
\hline $\begin{array}{l}\text { Mean EPC } \\
\text { band potential }\end{array}$ & $\mathrm{C} \mathrm{(78)}$ & $\mathrm{C} \mathrm{(75)}$ & $\mathrm{C}(77)$ \\
\hline $\begin{array}{l}\text { EPC } \\
\text { representation }\end{array}$ & $42 \%$ & $53 \%$ & $42 \%$ \\
\hline
\end{tabular}

\section{Survey results}

The online questionnaire received 41 responses with 28 in the actual mapped boundary (Rose Hill is a much larger area than the 431 dwellings in the final mapped area). In total, 57 questions were asked; most responses go directly into improving the model inputs. Table 2 lists a few statistically important questions and the responses. Insulation age informs U-value assumptions, e.g. loft insulation before 2008 is assumed to be $150 \mathrm{~mm}$, after
2008 is assumed to be up to $250 \mathrm{~mm}^{1}$. Most dwellings surveyed have double glazing; however, when asked about the proportion of single glazing some of those with double glazing $(\mathrm{n}=8)$ still had $50 \%$ or less single glazed windows.

Boiler age informs efficiency assumptions, e.g. before 1998 is assumed to be $0.7-0.78$ (depending on age of dwelling), between $1998-2005$ is assumed to be 0.85 , between $2005-2010$ is 0.88 , and after 2010 is 0.9 . Finally, all but two homes heat their home with gas, the other two using electricity. Half of the households use a secondary heating source in their home.

Table 2: Survey results ( $n=41$ responses).

\begin{tabular}{|c|c|}
\hline QUESTION & RESPONSE \\
\hline No. of occupants & 2.2 (average) \\
\hline Age of dwelling & 1930 (mode); 1935 (median) \\
\hline Loft insulation & $\begin{array}{l}\text { Installed before } 2008(n=13) ; \\
\text { Installed after } 2008(n=19) ; \text { None } \\
(n=2) ; \text { unknown }(n=6)\end{array}$ \\
\hline Wall insulation & $\begin{array}{l}\text { Installed before } 2008(n=9) \\
\text { Installed after } 2008(n=8) ; \text { None } \\
(n=7) ; \text { unknown }(n=16)\end{array}$ \\
\hline Draught proofing & $\begin{array}{l}\text { All }(n=14) ; \text { Most }(n=9) ; \text { Some } \\
(n=6) ; \text { None }(n=8)\end{array}$ \\
\hline Glazing & $\begin{array}{l}\text { Triple }(n=1) ; \text { Double }(n=33) ; \\
\text { Single }(n=4)\end{array}$ \\
\hline Boiler & $\begin{array}{l}\text { Installed before } 1998(n=4) ; \text { Inst. } \\
\text { between 1998-2005 }(n=7) ; \text { Inst. } \\
\text { between 2005-2010 }(n=8) ; \text { Inst. } \\
\text { after } 2010(n=19) ; \text { no boiler }(n=3)\end{array}$ \\
\hline Thermostat setting & $19^{\circ} \mathrm{C}$ (median); $19.3^{\circ} \mathrm{C}$ (mean) \\
\hline $\begin{array}{l}\text { Average cost of energy } \\
\text { bills }\end{array}$ & $\begin{array}{l}£ 925 \text { (median); £992 (mean); no } \\
\text { response }(\mathrm{n}=10)\end{array}$ \\
\hline $\begin{array}{l}\text { Annual gas } \\
\text { consumption }^{2}\end{array}$ & $\begin{array}{l}8,416 \mathrm{kWh} \text { (median); } 10,438 \mathrm{kWh} \\
(\text { mean); no response }(\mathrm{n}=27)\end{array}$ \\
\hline $\begin{array}{l}\text { Annual electricity } \\
\text { consumption }\end{array}$ & $\begin{array}{l}2,392 \mathrm{kWh} \text { (median); } 2,652 \mathrm{kWh} \\
\text { (mean); no response }(\mathrm{n}=27)\end{array}$ \\
\hline $\begin{array}{l}\text { Does the cost of fuel } \\
\text { influence how you heat } \\
\text { your home? }\end{array}$ & Yes $(n=26) ;$ No $(n=15)$ \\
\hline $\begin{array}{l}\text { Is } 10 \% \text { or more of your } \\
\text { annual net income used } \\
\text { to pay energy bills? }\end{array}$ & $\begin{array}{l}\text { Yes }(n=7) ; \text { No }(n=32) ; \text { no } \\
\text { response }(n=2)\end{array}$ \\
\hline $\begin{array}{l}\text { Are you interested in } \\
\text { energy efficiency work } \\
\text { and would you like to } \\
\text { be contacted? }\end{array}$ & Yes $(n=28) ;$ No $(n=13)$ \\
\hline
\end{tabular}

\section{DECoRuM baseline mapping}

Figure 1 shows the energy consumption for the dwellings in the mapped area.

- The mean energy consumption in the mapped area is $18,849 \mathrm{kWh} /$ year; $173 \mathrm{kWh} / \mathrm{m}^{2} /$ year.

\footnotetext{
12008 marked the beginning of the Carbon Emissions Reduction Target; predecessor to ECO (Ofgem, 2019a).

2 respondents were asked to consult energy bills and instructed on how to do so
} 
- The mean $\mathrm{CO}_{2} \mathrm{e}$ emissions for the area is 3,821 $\mathrm{kgCO}_{2} /$ year; $35 \mathrm{kgCO}_{2} / \mathrm{m}^{2} /$ year.

- Total mean gas consumption for the area is estimated through the DECoRuM model to be 15,159 $\mathrm{kWh} / \mathrm{year}$. This is between Ofgem's (Ofgem, 2019c) medium and high gas consumption value (Typical Domestic Consumption Values (TDCV)) for the UK.

- Total mean electricity consumption for the area is estimated to be $2,923 \mathrm{kWh} / \mathrm{year}$ this is just below the medium electricity value for Ofgem's TDCV.

Table 3 lists the retrofit potential for the mapped area.

Table 3: Baseline potential for retrofit.

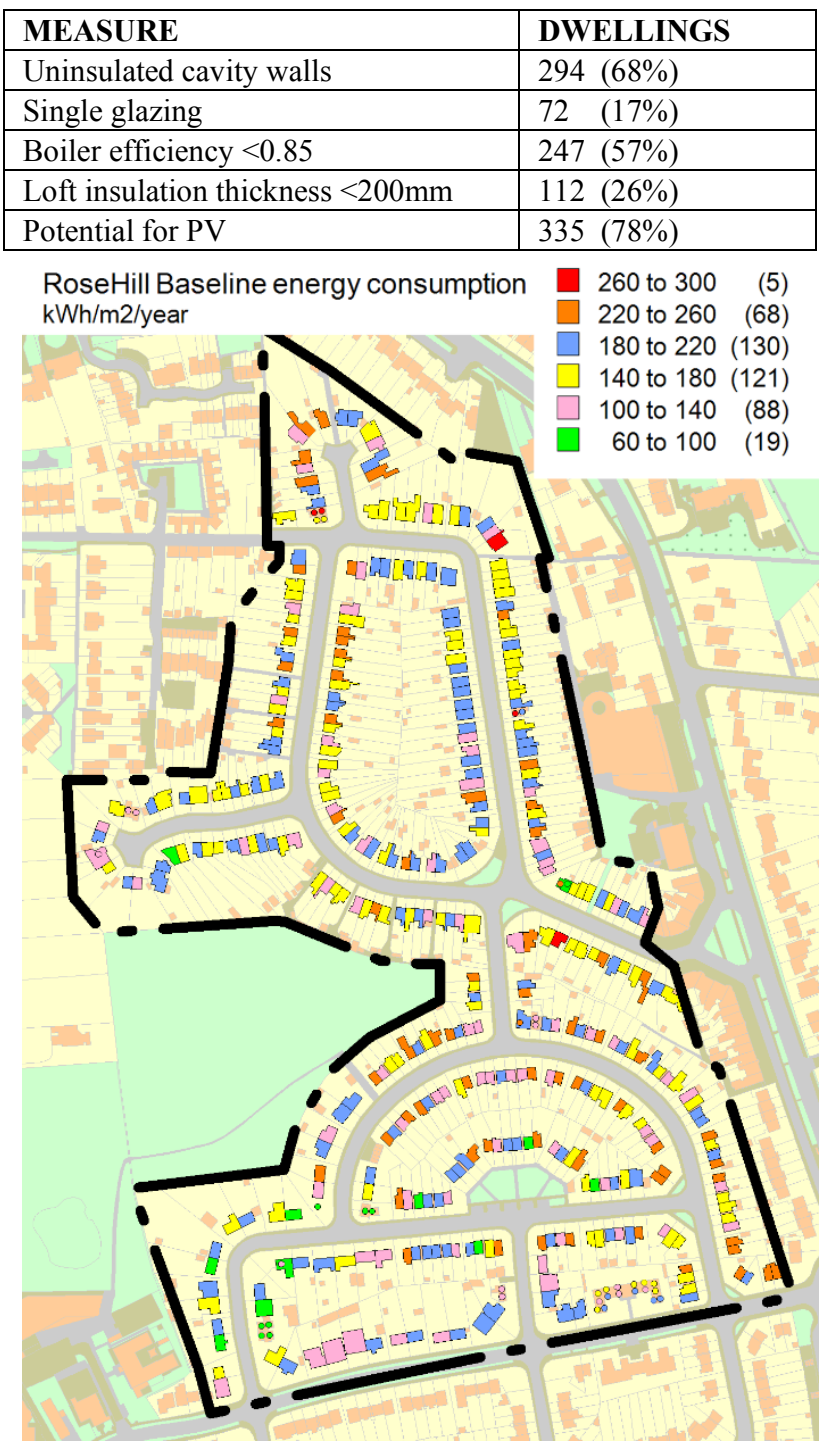

Figure 1: Baseline energy use. EPC data (MHCLG, 2017); Map (C Crown Copyright and Database Right 2018. Ordnance Survey (Digimap Licence).

\section{DECoRuM retrofit mapping}

To decide what measures were to be modelled for retrofit, the ECO3 measure table provided by $\mathrm{Ofgem}^{3}$ was used as $\mathrm{ECO} 3$ is the current version of the

${ }^{3}$ www.ofgem.gov.uk/system/files/docs/2018/12/eco3_me asures_table_v3.1.pdf obligation for the period of 2018-2022. The Ofgem table provides information on the energy efficiency measures which suppliers can install to meet their ECO3 obligations. The modelled measures are wall insulation, loft insulation, draught proofing, improved window glazing (from single to double), heating system upgrade (including pipework insulation, heating controls, 90\% efficiency boiler, hot water tank insulation), and PV.

Figure 2 shows the energy consumption for the dwellings in the mapped area following retrofit.

- The retrofitted mean energy consumption in the mapped area is projected to be $10,614 \mathrm{kWh} /$ year; 95 $\mathrm{kWh} / \mathrm{m}^{2} /$ year; an overall $44 \%$ reduction.

- The retrofitted mean $\mathrm{CO}_{2} \mathrm{e}$ emissions for the area is projected to be $2,179 \quad \mathrm{kgCO}_{2} /$ year; 20 $\mathrm{kgCO}_{2} / \mathrm{m}^{2} /$ year; an overall $43 \%$ reduction.

- The retrofit also resulted in an estimated $38 \%$ mean reduction in energy bills for the mapped area, a significant benefit to fuel poor households.

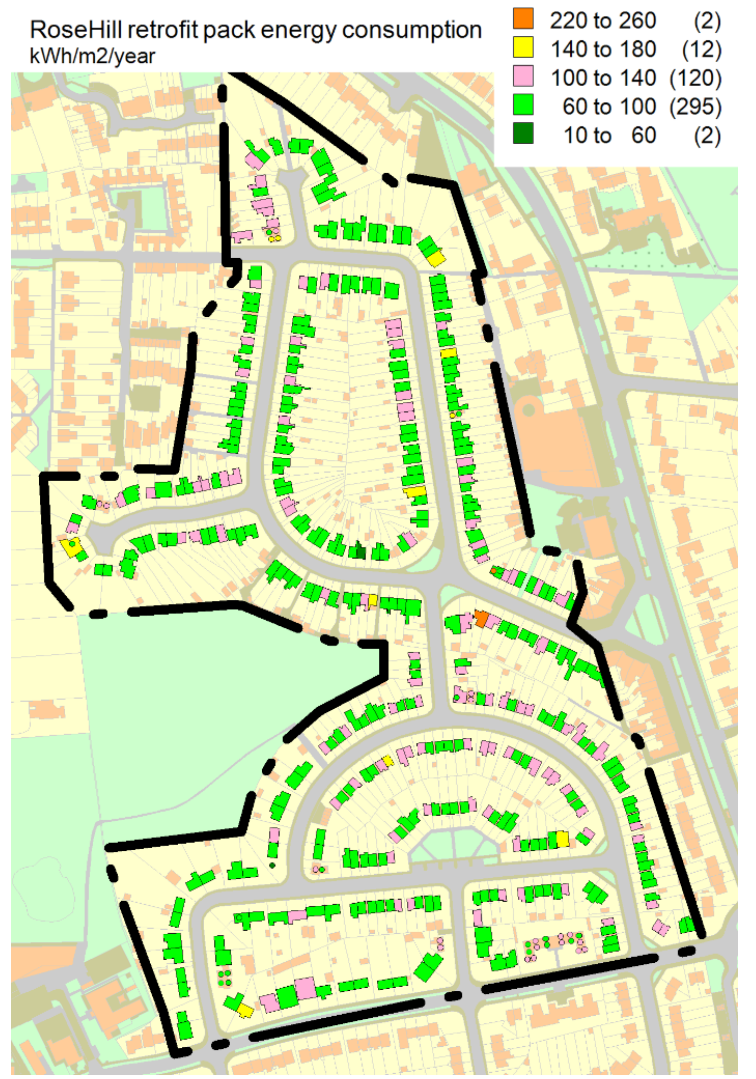

Figure 2: Retrofit package results. EPC data (MHCLG, 2017); Map $($ Crown Copyright and Database Right 2018. Ordnance Survey (Digimap Licence).

\section{Discussion}

Most of the innovation in energy retrofit work to date has been focussed on individual house demonstrators spread throughout the country (Gupta, Gregg, Passmore, $\&$ Stevens, 2015). However, in order to effectively and quickly scale-up alleviation of fuel poverty (Webber, Gouldson, \& Kerr, 2015), meet national carbon targets and improve the local economy (DECC, 2014) mass 
retrofits need to be intelligently targeted, cost-effective and result in a higher uptake.

Following the shift of involvement and action to reduce emissions from the central government to local government and community-based groups (Wade, Eyre, Parag, Hamilton, \& Lindström, 2013); local government and community groups require the tools to assess their local housing stock in order to improve it. The results from the DECoRuM, modelling and visualisation of estimated energy use and energy or $\mathrm{CO}_{2} \mathrm{e}$ emission reduction potential of individual household clusters, can provide useful feedback on retrofit need and progress to obligated energy suppliers, local authorities, community groups, residents, and retrofit providers.

Whereas it is traditionally up to the householder to seek out energy retrofit or accept offers for retrofit from salespersons or grants from local authorities on an individual house-by-house basis which could require serving randomly spread dwellings throughout a town or city, the proposed approach provides the Rose Hill and Iffley Low Carbon community group along with energy suppliers (responsible for the ECO), local authorities and housing providers with the information needed to rapidly pin-point local areas of high energy use or economic need and to identify potential grouped areas for retrofit.

After the local area is energy mapped, several approaches can be adopted to decide where to focus mass-retrofit depending on objectives, including:

1. Focus on common dwelling types which are likely to require the same type of retrofit measure or package of measures; DECoRuM generated maps can be used to pin-point specific dwelling types,

2. Focus on common measures required; maps can pinpoint dwellings that need a particular measure or combination of measures,

3. Focus on clusters, e.g. hot-spots of high energy consumption or economic need.

\section{Common dwellings type analysis}

Using the first method listed above, in order to create an organised approach for retrofit in the area, the four most common dwelling typologies are categorised, and details are extracted so that retrofit providers can use the information in order identify current status of the dwellings and potential needs. These dwellings types categorised by form and age-band are shown on the map in figure 3 and listed in table 4 with details that would be helpful for retrofit purposes. Estimated details, such as uninsulated walls, factor in what is known from EPCs, local observations, questionnaire input and typical dwellings characteristics.

The common typologies cover 387 dwellings $(90 \%)$ of the total 431 mapped. The remaining dwellings consist of a mix of terraced housing from the 1950s - 1970s and newly built dwellings or converted flats that make up infill ranging in age from 1990s - 2000s.

Though the 1930s terraced housing should not be ignored, especially as they make up a majority of dwellings in the area, the 1930s semi-detached dwellings appear to suggest a greater need for retrofit focus, whereas, almost $80 \%$ of the dwellings are estimated to be uninsulated in the walls, $34 \%$ still have single glazing, and have a greater proportion of dwellings with EPC efficiency ratings of $\mathrm{E}$ and $\mathrm{F}$.

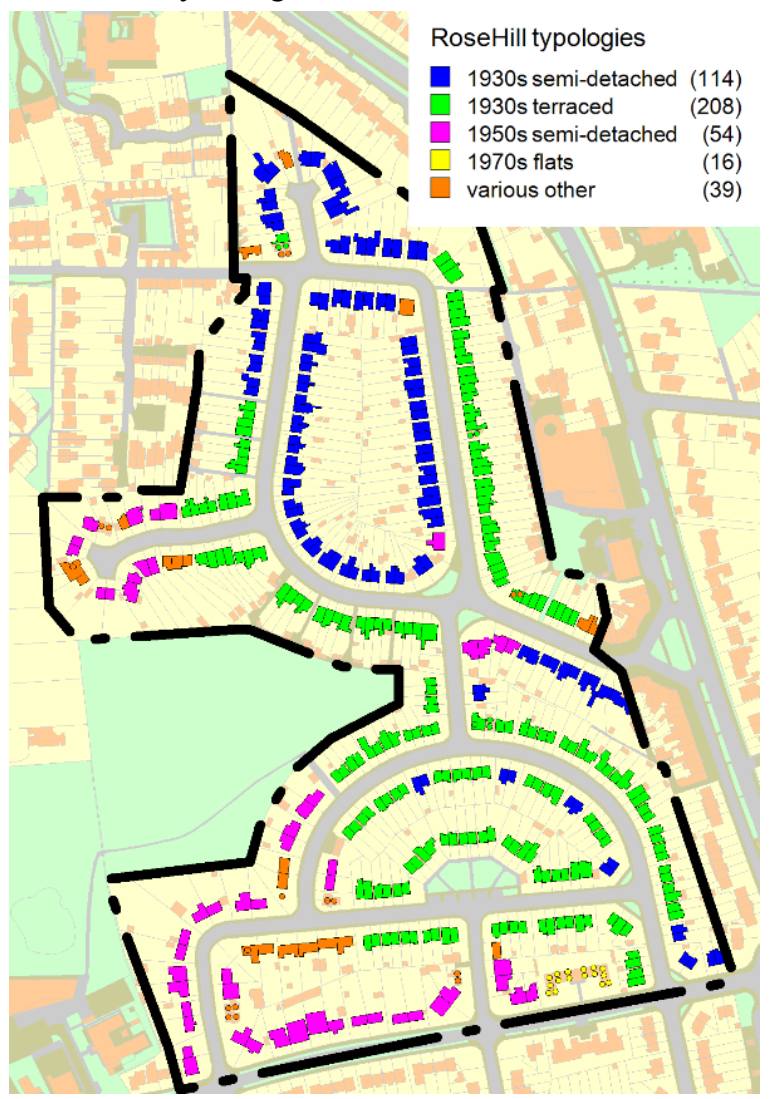

Figure 3: Common typologies. Map $₫$ Crown Copyright and Database Right 2018. Ordnance Survey (Digimap Licence).

\section{Retrofit measure focus by common dwellings type}

Using the second method combined with the first method listed above, if not packaging measures but retrofitting by single measures, table 5 provides the reduction potential for each of the following measures by dwelling type modelled in DECoRuM.

- Window upgrade / draughtproofing: where single glazing exists, all are replaced with double glazing in uPVC frame / Windows, doors, loft hatches and open fireplaces are draughtproofed.

- Wall insulation: Walls are cavity or solid wall insulated to $0.3 \mathrm{~W} / \mathrm{m}^{2} \mathrm{~K}$

- Roof / loft insulation: All lofts are insulated to $0.12 \mathrm{~W} / \mathrm{m}^{2} \mathrm{~K}$

- Heating system upgrade: Where necessary all boilers are upgraded to $90.3 \%$ efficiency boilers, where there are uninsulated hot water cylinders, these are insulated with $80 \mathrm{~mm}$ jackets, insulated primary pipework and cylinder thermostat also installed.

- PV: Depending on available roof area PV is installed. Average installed capacity potential $=$ $931 \mathrm{kWh} /$ year) 
Table 4: Common typology assessment.

\begin{tabular}{|c|c|c|c|c|}
\hline DETAILS & $\begin{array}{l}1930-1949 \\
\text { TERRACED }\end{array}$ & $\begin{array}{l}\text { 1930-1949 SEMI- } \\
\text { DETACHED }\end{array}$ & $\begin{array}{l}\text { 1950-1965 SEMI- } \\
\text { DETACHED }\end{array}$ & 1966-1976 FLAT \\
\hline Representative image & & & & \\
\hline \multicolumn{5}{|c|}{ BASELINE RESULTS } \\
\hline Dwellings count $(\%)$ & $208(48 \%)$ & $114(26 \%)$ & $54(13 \%)$ & $16(4 \%)$ \\
\hline $\begin{array}{l}\text { Uninsulated cavity } \\
\text { walls (est.) }\end{array}$ & $155(76 \%)$ & $90 \quad(79 \%)$ & $38(70 \%)$ & 0 \\
\hline Single glazing & $26(13 \%)$ & $39(34 \%)$ & $5(9 \%)$ & 0 \\
\hline Mean area & $98 \mathrm{~m}^{2}$ & $120 \mathrm{~m}^{2}$ & $148 \mathrm{~m}^{2}$ & $41 \mathrm{~m}^{2}$ \\
\hline $\begin{array}{l}\text { Mean space heating } \\
\text { consumption }\end{array}$ & $83 \mathrm{kWh} / \mathrm{m}^{2}$ & $101 \mathrm{kWh} / \mathrm{m}^{2}$ & $88 \mathrm{kWh} / \mathrm{m}^{2}$ & $61 \mathrm{kWh} / \mathrm{m}^{2}$ \\
\hline $\begin{array}{l}\text { Mean total energy } \\
\text { consumption }\end{array}$ & $\begin{array}{l}176 \mathrm{kWh} / \mathrm{m}^{2} \\
2 \% \text { greater than total } \\
\text { area mean consumption }\end{array}$ & $\begin{array}{l}186 \mathrm{kWh} / \mathrm{m}^{2} \\
7 \% \text { greater than total } \\
\text { area mean consumption }\end{array}$ & $\begin{array}{l}165 \mathrm{kWh} / \mathrm{m}^{2} \\
4 \% \text { less than total area } \\
\text { mean consumption }\end{array}$ & $\begin{array}{l}159 \mathrm{kWh} / \mathrm{m}^{2} \\
8 \% \text { less than total area } \\
\text { mean consumption }\end{array}$ \\
\hline EPC total count & 78 & 43 & 25 & 11 \\
\hline $\begin{array}{l}\text { EPC efficiency } \\
\text { ratings, total for each } \\
\text { rating }\end{array}$ & C, 18 & & & \\
\hline \multicolumn{5}{|c|}{ RETROFIT RESULTS } \\
\hline $\begin{array}{l}\text { Retrofitted mean } \\
\text { space heating } \\
\text { consumption }\end{array}$ & $47 \mathrm{kWh} / \mathrm{m}^{2}$ & $50 \mathrm{kWh} / \mathrm{m}^{2}$ & $48 \mathrm{kWh} / \mathrm{m}^{2}$ & $46 \mathrm{kWh} / \mathrm{m}^{2}$ \\
\hline $\begin{array}{l}\text { Retrofitted mean } \\
\text { total energy } \\
\text { consumption \& } \\
\text { reduction potential }\end{array}$ & $\begin{array}{l}94 \mathrm{kWh} / \mathrm{m}^{2} \\
46 \% \text { reduction in total } \\
\text { energy consumption } \\
\text { over baseline }\end{array}$ & $\begin{array}{l}94 \mathrm{kWh} / \mathrm{m}^{2} \\
49 \% \text { reduction in total } \\
\text { energy consumption } \\
\text { over baseline }\end{array}$ & $\begin{array}{l}90 \mathrm{kWh} / \mathrm{m}^{2} \\
45 \% \text { reduction in total } \\
\text { energy consumption } \\
\text { over baseline }\end{array}$ & $\begin{array}{l}106 \mathrm{kWh} / \mathrm{m}^{2} \\
33 \% \text { reduction in total } \\
\text { energy consumption } \\
\text { over baseline }\end{array}$ \\
\hline $\begin{array}{l}\text { Reduction in gas } \\
\text { consumption }\end{array}$ & $61 \mathrm{kWh} / \mathrm{m}^{2}(52 \%)$ & $72 \mathrm{kWh} / \mathrm{m}^{2}(56 \%)$ & $56 \mathrm{kWh} / \mathrm{m}^{2}(50 \%)$ & $33 \mathrm{kWh} / \mathrm{m}^{2}(29 \%)$ \\
\hline $\begin{array}{l}\text { Reduction in } \\
\text { electricity } \\
\text { consumption }\end{array}$ & $8 \mathrm{kWh} / \mathrm{m}^{2}(35 \%)$ & $6 \mathrm{kWh} / \mathrm{m}^{2}(27 \%)$ & $8 \mathrm{kWh} / \mathrm{m}^{2}(38 \%)$ & $18 \mathrm{kWh} / \mathrm{m}^{2}(44 \%)$ \\
\hline
\end{tabular}

Table 5: Individual measure energy $/ \mathrm{m}^{2}$ reduction potential by dwelling type.

\begin{tabular}{|l|l|l|l|l|}
\hline MEASURE & $\begin{array}{l}\text { 1930S } \\
\text { TER. }\end{array}$ & $\begin{array}{l}\text { 1930S } \\
\text { SEMI-D }\end{array}$ & $\begin{array}{l}\text { 1950S } \\
\text { SEMI-D }\end{array}$ & $\begin{array}{l}\text { 1970S } \\
\text { FLAT }\end{array}$ \\
\hline $\begin{array}{l}\text { Window } \\
\text { upgrade / } \\
\text { Draughtproof }\end{array}$ & $5 \%$ & $6 \%$ & $1 \%$ & $3 \%$ \\
\hline Wall ins. & $23 \%$ & $29 \%$ & $27 \%$ & $0 \%$ \\
\hline Roof ins. & $4 \%$ & $5 \%$ & $3 \%$ & $5 \%$ \\
\hline $\begin{array}{l}\text { Heat system } \\
\text { upgrade }\end{array}$ & $13 \%$ & $14 \%$ & $9 \%$ & $11 \%$ \\
\hline PV & $5 \%$ & $5 \%$ & $4 \%$ & $12 \%$ \\
\hline
\end{tabular}

If selecting a single measure by greatest reduction potential for the houses, wall insulation would be selected, followed by heating system upgrade. For the flats that are already insulated and double glazed, focusing on heating system upgrades and PV would provide more impact. After assessing the most effective measure approach, the individual houses of a select type can by queried regarding their need. Figure 3 would assist in identifying appropriate dwellings for this.

\section{Hot spots among common dwellings types}

Using the third method combined with the first method listed above, hot spots of high energy consumption can 
be identified among specific dwelling types. This allows a retrofit provider or retrofit planner from the community group or local authority to focus on a certain area categorising need with specific targets. Grouping these focal areas can help reduce time and costs. Figure 4 shows the mapped area with total energy consumption grouped into three ranges:

1. Above local and $\mathrm{UK}^{4}$ mean energy consumption $(>20,000 \mathrm{kWh} /$ year)

2. Local and UK mean energy consumption $(15,000-$ $20,000 \mathrm{kWh} /$ year)

3. Below local and UK mean energy consumption $(<15,000 \mathrm{kWh} /$ year $)$

The area within the blue box has a prominent high concentration of 1930s semi-detached dwellings with above average energy consumption. This would be a reasonable starting point for clustered large-scale retrofit action.

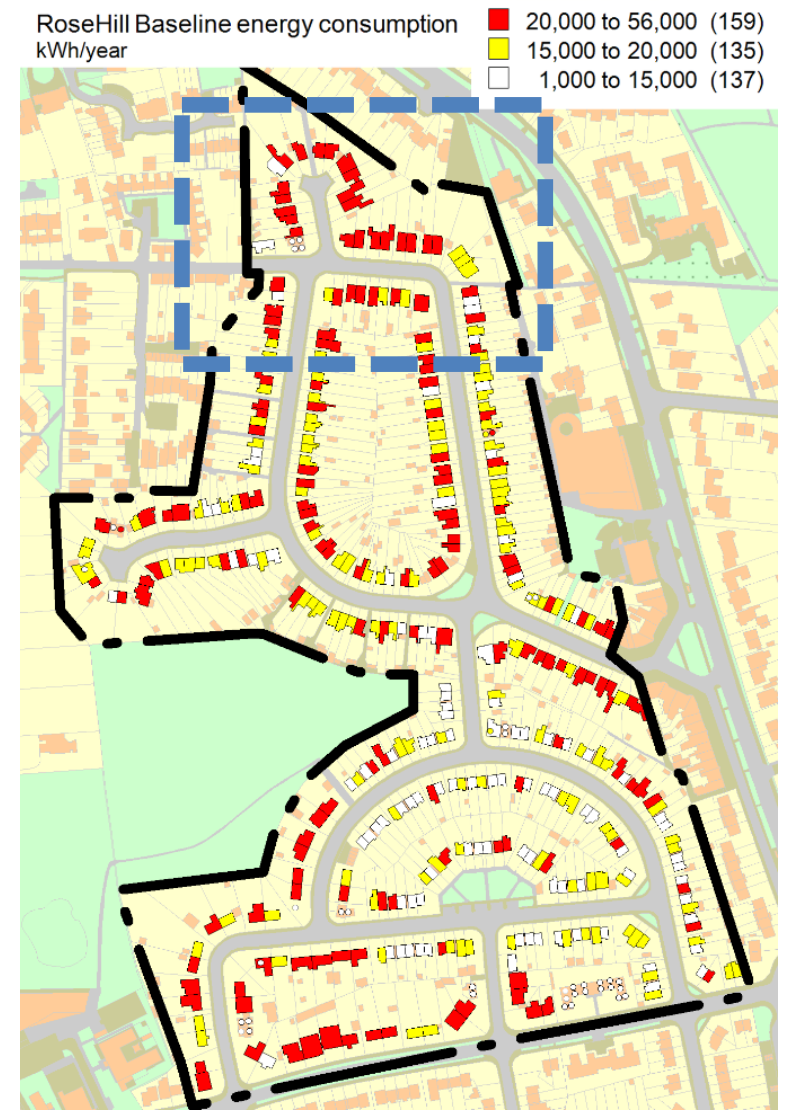

Figure 4: Retrofit package energy use. EPC data (MHCLG, 2017); Map $\odot$ Crown Copyright and

Database Right 2018. Ordnance Survey (Digimap Licence).

\section{Conclusion}

The house-by-house energy assessment using DECoRuM model shows that a package based approach comprising fabric and heating system upgrade and rooftop solar photovoltaics is effective in reducing energy use, emissions and fuel bills for the Rose Hill

\footnotetext{
${ }^{4}$ www.ofgem.gov.uk/gas/retail-market/monitoring-data-
} and-statistics/typical-domestic-consumption-values area. The proposed approach scientifically consolidates multiple data sources and analysis tools to deliver a spatial model for prioritising area-based energy reductions as part of a local energy strategy.

The spatial maps make energy use visible by highlighting local areas of high energy consumption, lack of existing improvement measures, and potential for energy improvements. Other benefits of the DECoRuM mapping outputs include:

- communication tool for planning change and funding,

- visual source for tracking retrofit progress and change,

- visualisation of smart meter data on a more frequency beyond annual consumption and emissions.

As smart meters are expected to be in every home in the UK by 2020 (BEIS, 2018b; Ofgem, 2019b) the connection with smart meters can also provide greater validation of modelling results. This link would also enable evaluation of area-wide trends in energy demand profiling which can be useful for introducing local time of use energy tariffs.

The next step in the project is to push forward with actual retrofit action. This would involve providing the results to the CAG, local authority and retrofit providers in the area and encourage the groups to work together to find efficient and cost-effective solutions to move forward.

\section{Acknowledgement}

The authors would like to thank the Rose Hill and Iffley Low Carbon community group (RHILC), especially Eleanor Watts for her assistance with dwelling selection and community engagement. The authors would also like to thank Eleanor Watts, Chris Jacques, and Wendy Nicholls of RHILC, Doug Drewniak at Bioregional, Kat Luddecke at the Low Carbon Hub, and Alastair Howard at the Low Carbon Building Group, Oxford Brookes University for pilot testing the home energy questionnaire in their own homes and providing feedback.

\section{References}

Ariffin, S. T., Sulaiman, S., Mohammad, H., Yaman, S. K., \& Yunus, R. (2016) Factors of economies of scale for construction contractors. Paper presented at the International Congress on Technology, Engineering, and Science (IConTES 2016), Vistana Hotel, Kuala Lumpur, Malaysia.

BEIS. (2017a). Fuel poverty data measured as low income high costs (2015 data) [Data set]. Retrieved from https://www.gov.uk/government/statistics/subregional-fuel-poverty-data-2017

BEIS. (2017b). Sub-national consumption statistics. Retrieved Date Accessed, 2013 from https://www.gov.uk/government/publications/regiona 1-energy-data-guidance-note.

BEIS. (2018a). Clean growth strategy: Leading the way to a low carbon future. London: HM Government 
Retrieved from

https://assets.publishing.service.gov.uk/government/u ploads/system/uploads/attachment data/file/700496/c lean-growth-strategy-correction-april-2018.pdf.

BEIS. (2018b). Smart meters: A guide. London: GOV.UK Retrieved from

https://www.gov.uk/guidance/smart-meters-howthey-work.

BRE. (2014). Building typology brochure england: September 2014 296-024). Watford: B. R.

Establishment.

http://episcope.eu/fileadmin/tabula/public/docs/broch ure/GB_TABULA_TypologyBrochure_BRE.pdf

Bruce-Konuah, A., \& Gupta, R. (2017). Using smart energy storage to increase self-consumption of solargenerated electricity and reduce peak grid load at household and community level. ECEEE summer study proceedings.

Cabinet Office, D., DCLG. (2011). Behaviour change and energy use. $\mathrm{p} 35$.

Caputo, P., \& Pasetti, G. (2017). Boosting the energy renovation rate of the private building stock in italy: Policies and innovative gis-based tools. Sustainable Cities and Society, 34, pp. 394-404.

Cityfied Project. (2015). Building solutions for boosting the energy retrofitting of buildings and districts in the cities of valladolid and malaga (spain). Retrieved Date Accessed, 2017 from http://www.cityfied.eu/News/PressReleases/Finding-Solutions-For-Boosting-TheEnergy-Retrofitting-Of-Buildings-And-Districts-InThe-Cities-Of-Valladolid-And-Malaga-Spain.kl.

Cousins, A., Gitsham, M., \& Joss, A. (2010). Retrofit at scale: Refurbishing homes in bristol. Retrieved Date Accessed, 2018 from https://www.forumforthefuture.org/retrofit-scale.

CSE. (2017). National heat map: New web-based tool to support low-carbon energy projects. Retrieved Date Accessed, 2017 from https://www.cse.org.uk/projects/view/1183.

de Santoli, L., Mancini, F., \& Garcia, D. A. (2018). A gis-based model to assess electric energy consumptions and usable renewable energy potential in lazio region at municipality scale. Sustainable Cities and Society

Delmastro, C., Mutani, G., \& Schranz, L. (2016). The evaluation of buildings energy consumption and the optimization of district heating networks: A gisbased model. International Journal of Energy and Environmental Engineering, 7(3), pp. 343-351.

EIT, \& NTU. (2018). Scaling up retrofit 2050. Stevenage: https://www.theiet.org/factfiles/builtenv/retrofit.cfm

Emden, J., Murphy, L., \& Lloyd, H. (2018). Beyond eco: The future of fuel poverty support. London: T. I. f. P. P. Research. https://www.ippr.org/files/2018-07/fuelpoverty-june18-final.pdf

Groppi, D., de Santoli, L., Cumo, F., \& Garcia, D. A. (2018). A gis-based model to assess buildings energy consumption and usable solar energy potential in urban areas. Sustainable Cities and Society, 40, pp. 546-558.

Gupta, R. (2009). A new geographical information system-based approach to map and reduce energyrelated co2 emissions from uk dwellings. Eleventh International IBPSA Conference.

Gupta, R., \& Gregg, M. (2013). Preventing the overheating of english suburban homes in a warming climate. Building Research \& Information, 41(3), pp. 281-300.

Gupta, R., \& Gregg, M. (2018) A new gis based decision support tool for enabling local energy retrofits. Paper presented at the Building Simulation and Optimization 2018, Emmanuel College, University of Cambridge.

Gupta, R., Gregg, M., Passmore, S., \& Stevens, G. (2015). Intent and outcomes from the retrofit for the future programme: Key lessons. Building Research \& Information, 43(4), pp. 435-451.

MHCLG. (2017). Energy performance of buildings data: England and wales. Retrieved Date Accessed, 2019 from https://epc.opendatacommunities.org/.

Moghadam, S. T., Mutani, G., \& Lombardi, P. (2016). Gis-based energy consumption model at the urban scale for the building stock. 9th International Conference, Improving Energy Efficiency in Commercial Buildings \& Smart Communities Conference (IEECB \& SC'16), Frankfurt.

Ofgem. (2019a). Overview of previous schemes. Retrieved Date Accessed, 2019 from https://www.ofgem.gov.uk/environmentalprogrammes/eco/overview-previous-schemes.

Ofgem. (2019b). Smart meters: Your rights. Retrieved Date Accessed, 2019 from

https://www.ofgem.gov.uk/consumers/householdgas-and-electricity-guide/understand-smartprepayment-and-other-energy-meters/smart-metersyour-rights.

Ofgem. (2019c). Typical domestic consumption values. Retrieved Date Accessed, 2019 from https://www.ofgem.gov.uk/gas/retailmarket/monitoring-data-and-statistics/typicaldomestic-consumption-values.

Quan, S. J., Li, Q., Augenbroe, G., Brown, J., \& Yang, P. P.-J. (2015). Urban data and building energy modeling: A gis-based urban building energy modeling system using the urban-epc engine Planning support systems and smart cities (pp. 447469): Springer.

Wade, J., Eyre, N., Parag, Y., Hamilton, J., \& Lindström, T. (2013). Local energy governance: Communities and energy efficiency policy. Proceedings: ECEEE 2013 Summer Study on Energy Efficiency, pp. 637-648.

Webber, P., Gouldson, A., \& Kerr, N. (2015). The impacts of household retrofit and domestic energy efficiency schemes: A large scale, ex post evaluation. Energy Policy, 84, pp. 35-43. 